\title{
Dialil Disülfit ve Dialil Trisülfit'in İnsan Prostat Kanser Hücreleri Üzerine Sitotoksik, Genotoksik ve Apoptotik Etkileri
}

\section{Cytotoxic, Genotoxic and Apoptotic Effects of Diallyl Disulfide and Diallyl Trisulfide on Human Prostate Cancer Cells}

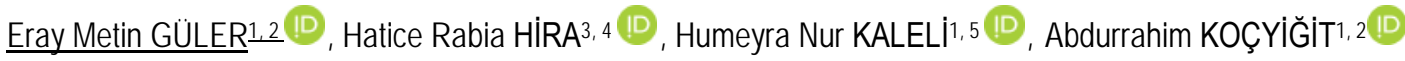

\begin{abstract}
1 Bezmialem Vakıf Üniversitesi Tıp Fakültesi Tıbbi Biyokimya Anabilim Dalı, İstanbul
2 Bezmialem Vakı Üniversitesi Geleneksel ve Tamamlayıcı Tıp İleri Araştıma ve Uygulama Merkezi, İstanbul

3 Bezmialem Vakıf Üniversitesi Tıp Fakültesi, İstanbul

4 Sağlık Bilimleri Üniversitesi Ümraniye Eğitim ve Araştırma Hastanesi Kadın Hastalıkları ve Doğum Anabilim Dalı, İstanbul

5 Sabancı Üniversitesi Moleküler Biyoloji, Genetik ve Biyomühendislik Programı, İstanbul
\end{abstract}

Öz.

Amaç: Kanser dünya çapında artan bir sağlık sorunu olup, erkeklerde en sık görülen kanser türü olan prostat kanseri, birçok ülke için ikinci ölüm nedenidir. Kanser tedavisinde konvansiyonel yöntemlerin başarısız olması nedeni ile doğal etken maddelerin kullanımı son yıllarda giderek daha fazla ilgi görmektedir. Bu çalışmanın amacı, Sarımsak (Allium sativum) etken maddelerinden olan, Dialil Disülfit (DADS) ve Dialil Trisülfitin (DATS) farklı konsantrasyonlarının insan prostat kanser hücreleri üzerine sitotoksik, genotoksik ve apoptotik etkilerini araştırmaktır.

Materyal ve Metod: Bu çalışmada prostat kanser (PC-3) ve sağlıklı prostat epitel hücrelerine (WPMY-1) DADS ve DATS'ın sitotoksik etkisi luminometrik ATP testiyle, genotoksik etkisi alkalen tekli hücre jel elektroforez (Comet Assay) yöntemiyle, apoptotik etkisi akridin turuncusu/etidyum bromür yöntemiyle ölçüldü. Ayrıca, mitokondriyal membran potansiyeli (MMP), hücre içi kalsiyum (Ca2+) ve reaktif oksijen türlerinin (ROS) seviyeleri farklı florometrik yöntemlerle ve glutatyon seviyeleri ise luminometrik yöntem ile tayin edildi.

Bulgular: DADS ve DATS doza bağımlı olarak hem kanser hem de normal hücrelerde glutatyon ve MMP seviyelerini anlamlı sekilde düsürürken, sitotoksisite, DNA hasarı, apoptoz, hücre içi Ca2+ ve ROS düzeylerini anlamlı derecede arttırmıştı. Ayrıca, DATS'ın kanser hücreleri üzerine sitotoksik, genotoksik ve apoptotik etkileri sağıklı hücrelere ve DADS'a göre daha yüksek bulunmustur.

Sonuç: Bulgular hem DADS hem de DATS'ın prostat kanseri hücrelerinde doza bağlı bir şekilde sitotoksik, genotoksik ve apoptotik etkilere sahip olduğunu ve DATS'ın DADS'a göre daha etkili olduğunu göstermiştir. Bu nedenle, DATS'ın prostat kanseri tedavisi için kullanılabilecek seçeneklerden biri olabileceğini önermekteyiz.

Anahtar Kelimeler: Prostat kanseri, Dialil disülfit, Dialil trisülfit, Kanser tedavis

Abstract

Background: Cancer is an increasing health problem worldwide; however, prostate cancer is the most common cancer in men and the second leading cause of death in many countries. Due to the failure of conventional methods in the treatment of cancer, the use of natural active ingredients in cancer treatment has gained increasing attention in recent years. The aim of this study is to investigate cytotoxic, genotoxic, and apoptotic effects of different concentrations of diallyl disulfide (DADS) and diallyl trisulfide (DATS) on human prostate cancer cells.

Materials and Methods: In this study, the cytotoxic effect of DADS and DATS in prostate cancer (PC-3) and healthy prostate epithelial cells (WPMY-1) was measured by luminometric ATP test, the genotoxic effect was measured by alkaline single-cell electrophoresis (Comet Assay) method, and apoptotic effect by acridine orange/ethidium bromide method. In addition, mitochondrial membrane potential (MMP), intracellular calcium (Ca2+), and reactive oxygen species (ROS) levels were measured by different fluorometric methods, and glutathione levels were determined by the luminometric method.

Results: DADS and DATS reduced statistically significantly glutathione and MMP levels while increased cytotoxicity, DNA damage, apoptosis, intracellular $\mathrm{Ca} 2+$, and ROS levels in both cancer and healthy cells dose-dependent manner. In addition, the cellular effects of DATS were higher than DADS in cancer cells than healthy cells.

Conclusion: The findings showed that both DADS and DATS have a dose-dependent cytotoxic, genotoxic and apoptotic effect in prostate cancer cells and that DATS is more effective than DADs. Therefore, we suggest that DATS may be one of the options available for the treatment of prostate cancer.

Key words: Prostate cancer, Diallyl disulfide, Diallyl trisulfide, Cancer treatment

\section{Sorumlu Yazar I \\ Corresponding Author}

Dr. Eray Metin Guler

Bezmialem Vakıf Üniversitesi

Tıp Fakültesi Tıbbi Biyokimya A. D.

34093, Fatih - İstanbul

e mail: eraymetinguler@gmail.com

Tel: 5553778476

Geliş tarihi / Received:

08.06.2020

Kabul tarihi / Accepted:

21.07.2020

DOI: $10.35440 /$ hutfd. 749554

Bu çalışma 14 Mart 2017'de

Bezmialem Vakıf Üniversitesi

"Annual Medical Students Research

Presentation Day" de kısa sözlü

bildiri olarak sunulmuştur. 


\section{Giriş}

Prostat kanseri, gelişmiş ülkelerdeki erkeklerde en ölümcül ürogenital sistem hastalığıdır (1). Terapötik yöntemlerin etkinliğinde büyük gelişme sağlanmış olsa da, çoğu prostat kanserinde, ilaca karşı direnç ile tedavi öncesi ve sonrası oluşan metastaz tedavideki büyük bir engeldir (2). Konvansiyonel tedavi yöntemleri olan cerrahi, tümör ablasyon tedavisi kemoterapi ve radyoterapi yöntemlerinin yetersiz kalması, direnç gelişmesi, nüks etmesi ve ciddi yan tesirler gibi nedenlerle alternatif tedavi arayışları sürmektedir. Alternatif tedavi yöntemlerinden bir de bitkisel doğal etken maddelerin kullanımıdır (3). Yapılan çalışmalar, bitki kaynaklı bileşikler veya bu bileşiklerin düşük toksisitesi ve kanser hücrelerini öldürmek için yüksek seçiciliği olan aktif bileşenleri üzerinde odaklanmıştır.

Sarımsak (Allium sativum) esas olarak gıda olarak kullanılan, Liliaceae familyasına ait otsu bir bitkidir. Sülfür içeren bileşiklerden oluşan sarımsak \% 65 su, $\% 30$ karbohidrat ve $\% 5$ diğer bileşenlerden oluşur (4). Yapılan son çalışmalar sarımsağın içerdiği kükürtlü bileşiklerin antiviral, antifungal, antibakteriyal (5), antioksidan (6), antikanser (7), immünmodülatör (5), antihipertansif, antiaterosklerotik (8), antiprotozoal (9) özellikler gibi çeşitli farmakolojik etkileri olduğunu göstermiştir. Sarımsağın etken maddelerinden dialilsülfit (DAS), dialildisülfit (DADS) ve dialiltrisülfit (DATS) bileşiklerinin karsinojenezi (10) ve hücre döngüsünü inhibe ettikleri, hücre içi reaktif oksijen türlerinin (ROS) düzeylerini arttırarak, apoptozu indüklemesi yoluyla çeşitli kanser hücrelerinin proliferasyonunu inhibe ettiği bildirilmiştir (11). Bununla birlikte, bu bileşiklerin farklı konsantrasyonlarının prostat kanseri hücreleri ile birlikte sağlıklı prostat hücreleri üzerine DNA hasarı, apoptoz ve hücre içi ROS üretim kapasitelerini birlikte araştıran bir çalışmaya rastlanılmamıştır. Ayrıca apoptozu indükleyen MMP ve $\mathrm{Ca}^{2+}$ düzeylerini araştıran bir çalışma ile ilgili bir literatür bilgi bulunamamıştır. Bu çalışma ile amacımız, DADS ve DATS'ın prostat kanseri üzerine sitototoksik, genotoksik, apoptotik etkileri ile hücre içi ROS üretim seviyeleri arasındaki ilişkiyi araşıımaktır.

\section{Materyal ve Metod \\ Materyal}

DADS, DATS, fetal sığır serumu (FBS), F12K besiyeri, Dulbecco's Modified Eagle besiyeri (DMEM), dimetilsülfoksit (DMSO), Fura-2AM, 2'7'-diklorodihidrofloreskein diasetik asit $\left(\mathrm{H}_{2} \mathrm{DCF}-\mathrm{DA}\right)$, penislin/streptomisin (P/S), akridin turuncusu (AT), etidyum bromür (EB), 3,3'-diheksilokarbosiyanin iyodit (DiOC6(3)) Sigma-Aldirch (Seelze, Almanya)'ten temin edildi. Luminometrik ATP kiti Promega (CellTiter-Glo® Luminescent Cell Viability Assay, Madison, ABD)'dan temin edildi. Deneylerde kullanıan diğer kimyasal ve solüsyonların hepsi analitik kalitede kullanıldı.

\section{Metot \\ Hücre kültürü çalışmaları}

Amerikan Tip Kültür Koleksiyonu (ATCC)'den ticari olarak satın alınan insan prostat kanser hücresi PC-3 (ATCC ${ }^{\circledR}$ CRL1435 ${ }^{\mathrm{TM}}$ ) ve sağlıklı insan prostat epitel hücresi WPMY1 (ATCC $®$ CRL2854 ${ }^{\mathrm{TM}}$ ) çalışmalarda kullanıldı. PC-3 ve WPMY-1 hücre hatları F12K ve DMEM besiyerlerinde $\% 10$ FBS ve $\% 1 \mathrm{P} / \mathrm{S}$ içeren complete besiyerlerinde $37^{\circ} \mathrm{C}$ 'de $\% 5 \mathrm{CO}_{2}$ içeren inkübatörlerde kültüre edilip, çoğaltıldı. Sitotoksisite, hücre içi ROS, kalsiyum, mitokondriyal membran potansiyeli ve hücre içi kalsiyum düzeyleri için $96^{\prime \prime}$ ı plakalara kuyu başı $15 \times 10^{3}$ hücre, genotoksisite ve apoptoz

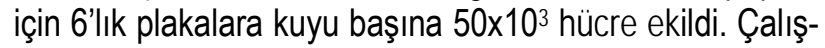
madaki tüm ekimler hücrelerin yapışması için 24 saatlik inkübasyon, verilen maddelerin sitotoksik, genotoksik ve apoptotik ve diğer etkilerini incelemek için $37^{\circ} \mathrm{C}$ 'de 24 saatlik inkübasyona bırakııdı. Bütün deneylerden önce hücrelerin canlılıkları tripan mavisi ile 1:1 oranında karıştırııp thoma lamında sayıldı.

\section{Sitotoksisite testi}

Çalışmada sitotoksisiteyi tespit edebilmek için luminometrik ATP testi kullanıldı. Ticari olarak satın alınan CellTiterGlo® luminesans hücre canlılık kiti canlı hücrelerin varllğını işaret eden ATP miktarına dayalı homojen bir yöntemdir. Yöntemin prensibi, ATP miktarı hücre sayısı ile orantılı olduğundan dolayı ortamdaki lusiferin hücrelerdeki ATP varlığında rekombinant lusiferaz enzimi ile oksilusiferine dönüşerek luminesans yayar (12). Opak beyaz 96 'lık plakalara ekilen kuyu başı $15 \times 10^{3}$ hücreye 24 saat sonra farklı konsantrasyonlarda hazırlanan DADS $(1-400 \mu \mathrm{M})$ ve DATS (1-400 $\mu \mathrm{M})$ eklendi ve 24 saat inkübe edildi. İnkübasyonun ardından ATP solüsyonu eklenip 5 dakika içinde multiplaka okuyucuda (Varioskan Flash Çok Modlu Okuyucu, Thermo, Waltham, ABD) luminometrik yöntem ile ölçüldü. ATP varlığında yayılan luminesans, relatif lüminesans birimleri (RLU) olarak belirtildi. Hücre canlılığı, $\% 100$ olarak kabul edilen kontrol grubuna göre ifade edildi (Şekil 1). Doğrusal olmayan regresyon analizi doz cevap eğrilerinden yarı maksimum büyüme inhibitör konsantrasyonu $\left(\mathrm{IC}_{50}\right)$ değerleri hesaplandı. Tüm dozlar dört kez tekrarlandı.

\section{Hücre içi ROS ölçümü}

Hücre içi ROS üretimi, floresan sinyal göstergesi 2,7 diklorodihidrofloreskein diasetik asit $\left(\mathrm{H}_{2}\right.$ DCF-DA) kullanilarak değerlendirildi. Renksiz olan $\mathrm{H}_{2}$ DCF-DA ortamdaki ROS ile oksitlenir ve yeşil floresans özellikteki diklorofloreskeine (DCF) dönüşür. Artan ROS miktarı ile yayılan floresans arasında floresans korelasyon vardır. 96'lık siyah opak plakalara ekilen kuyu başı $15 \times 10^{3}$ hücreye 24 saat sonra farklı konsantrasyonlarda hazırlanan DADS $(1-400 \mu \mathrm{M})$ ve DATS (1-400 $\mu \mathrm{M})$ eklendi. İnkübasyon sonrası besiyerleri aspire $1 \mathrm{xPBS}$ ile 3 kere yıkandı. $\mathrm{ddH}_{2} \mathrm{O}^{\prime}$ da hazırlanan 100 $\mu \mathrm{L} 10 \mu \mathrm{M} \mathrm{H}{ }_{2}$ DCF-DA eklenip $37^{\circ} C^{\prime}$ 'de 30 dakika inkübe edildi. Inkübasyon sonrası oluşan DCF'nin floresans yoğunluğu Ex:488nm/Em:525nm floresans plaka okuyucusu (Varioskan Flash Çok Modlu Okuyucu, Thermo, Waltham, 
ABD) kullanılarak ölçüldü. Sonuçlar \% 0,1 DMSO eklenen kontrol grubuna göre relatif olarak ATP ile kiyaslanarak (ROS/ATP) hesaplandı (13). Tüm dozlar dört kez tekrarlandı.

\section{Hücre içi kalsiyum ölçümü}

Hücre içi kalsiyum düzeyi, floresans özellikte olan Fura2AM boyası kullanılarak değerlendirildi. 96'ık siyah opak plakalara ekilen kuyu başı $15 \times 10^{3}$ hücrelere 24 saat sonra farklı konsantrasyonlarda hazırlanan DADS $(1-40 \mu \mathrm{M})$ ve DATS $(1-40 \mu \mathrm{M})$ eklenip, 24 saat inkübe edildi. İnkübasyon sonrası besiyerleri aspire edilip 1xHBSS ile yıkandı. Kuyulara $100 \mu \mathrm{L} 5 \mu \mathrm{M}$ Fura-2AM eklenip 30 dakika oda sıcaklığında inkübe edildi. Hücreler 1 xHBSS ile 2 kere yıkandıktan sonra $1 \mathrm{xHBSS}$ ile 45 dakika oda sıcaklığında inkübasyondan sonra oluşan floresans yoğunluğu Ex:340nm/Em:380nm floresans plate okuyucusu (Varioskan Flash Çok Modlu Okuyucu, Thermo, Waltham, ABD) kullanılarak ölçüldü. Sonuçlar \%0,1 DMSO eklenen kontrol grubuna göre relatif olarak ATP ile kıyaslanarak $\left(\mathrm{Ca}^{2+} / \mathrm{ATP}\right)$ hesaplandı. Tüm dozlar dört kez tekrarlandı (14).

\section{Mitokondriyal membran potansiyeli ölçümü}

Mitokondriyal membran potansiyeli (MMP), mitokondriyal fonksiyonun önemli bir parametresi ve hücre sağlığının bir göstergesidir. MMP'nin düşmesi proapoptotik sinyalin başlatılmasını yansıtan mitokondriyal zar bütünlüğünün kaybına işaret eder. Bu protokolde, mitokondride biriken bir hücre geçirgen, yeşil floresans, lipofilik boya 3.3'diheksiloksikarbosiyanin iyodür (DiOC6(3)) kullanıldı. DADS ve DATS farklı konsantrasyonlarının (1-40 $\mu \mathrm{M}) 24$ saatlik inkübasyonu sonrası besiyeri kaldırılıp yıkandıktan sonra 40 nM DiOC6(3) ile $37^{\circ} \mathrm{C}$ 'de 15 dakika inkübe edildikten sonra 1xPBS ile 3 kere yıkandıktan sonra floresans yoğunluğu Ex:484nm/Em:501 nm floresans plaka okuyucusu (Varioskan Flash Çok Modlu Okuyucu, Thermo, Waltham, ABD) kullanılarak ölçüldü. Sonuçlar kontrol grubuna göre relatif olarak ATP ile kıyaslanarak (MMPIATP) hesaplandı (13, 15). Tüm dozlar dört kez tekrarlandı.

\section{Glutatyon ölçümü}

Çalışmada hücre içi glutatyon düzeylerini ölçmek için luminometrik glutatyon kiti kullanıldı. Ticari olarak satın alınan GSH-Glo ${ }^{\mathrm{TM}}$ Glutathione Assay luminesans glutatyon kiti glutatyonu glutatyon-s transferaz enzimiyle indirgerken kitte bulunan lusiferin-NT substratını lusiferine dönüştürür. Bu dönüşüm sırasında ortamda ATP çıkar. Ortamda meydana gelen lusiferin rekombinant lusiferaz enzimi ile oksilusiferine dönüşerek luminesans yayar (16). Opak beyaz 96'ık plakalara ekilen kuyu başı $15 \times 10^{3}$ hücreye 24 saat sonra farklı konsantrasyonlarda hazırlanan DADS (1-40 $\mu \mathrm{M})$ ve DATS $(1-40 \mu \mathrm{M}) 24$ saat inkübe edildi. İnkübasyonun ardından glutatyon solüsyonu eklenip 5 dakika içinde Thermo Varioskan multiplaka okuyucuda luminesans ölçüm alındı. Sonuçlar \% 0,1 DMSO eklenen kontrol grubuna göre relatif olarak ATP ile kıyaslanarak (GSH/ATP) hesaplandı. Tüm dozlar dört kez tekrarlandı.

\section{DNA hasarı ölçümü}

Genotoksik hasar yani DNA hasarı Singh ve arkadaşları tarafından geliştirilen alkalen tekli hücre jel elektroforezi yöntemi (Comet Assay) ile ölçüldü (17). Comet Assay metodu DNA'nın farklı elektriksel yük ve ağırlığına göre elektrik alanında farklı göç etmesine dayalı bir yöntemdir. Hücreler agaroza yerleştirilip lizise uğratııı. Eğer DNA'da herhangi bir hasar (genotoksisite) yoksa DNA görünümü kompakttır yani herhangi bir kuyruk (comet) oluşturmaz. Oysa DNA hasara uğrayıp fragmente olmuşsa, oluşan bu fragmentler farklı elektriksel yük ve molekül ağırlığına sahip oldukları için elektroforetik ortamda farklı hareket edeceklerinden, DNA'lar floresan boya olan etidyum bromür ile boyandıklarında kuyruklu bir görüntü oluşturacaklardır (17, 18). DADS ve DATS'ın genotoksik potansiyelini belirlemek için kuyu başı $50 \times 10^{3}$ olacak şekilde 6'lık plakalara ekilen 2 farklı hücreye $\mathrm{IC}_{50}$ altındaki dozlarda $(1-40 \mu \mathrm{M})$ tedavi uygulandıktan 24 saat sonra tripsin-EDTA ile kaldırıldı. 1xPBS ile yıkanan hücreler $+4^{\circ} \mathrm{C}$ 'de $500 \mathrm{xg}$ 'de 5 dakika santrifüj ardından süpernatant atıldı. $10 \mu \mathrm{L}$ hücre süspansiyonu, $85 \mu \mathrm{L} \% 0,65$ düşük erime noktalı agaroz (LMA) ile karıştırııp, \%1 normal erime noktalı agaroz (NMA) ile önceden kaplanmış lamlara ilave edilip donduktan sonra örnekler $+4^{\circ} \mathrm{C}$ 'de lizis çözeltisinde 4 saat inkübe edildi. İnkübasyondan sonra örnekler soğuk 1xPBS ile yıkanıp $+4^{\circ} \mathrm{C}$ 'de elektroforez tamponunda DNA'daki bağların açılması için 40 dakika tekrar inkübe edildi. Daha sonra örnekler elektroforezde $+4^{\circ} \mathrm{C}$ 'de $26 \mathrm{~V}, 300 \mathrm{~mA}$ 'de 25 dakika yürütüldü. Lamlar 3 kere nötralizasyon tamponunda yıkandıktan sonra etanol ile fikse edildi. Kurutulmuş örneklere etidyum bromür $(2 \mu \mathrm{g} / \mathrm{mL})$ damlatilip floresans mikroskopta (Leica DM 1000, Solms, Almanya) görüntü alındı. Görüntülerdeki DNA kuyruk yüzdeleri Comet Assay IV analiz programı ile analiz edildi.

\section{Apoptoz ölçümü}

Akridin turuncusu/etidyum bromür boyası (AT/EB), hücrelerde morfolojik değişikliklerin değerlendirilmesi için kullanılan çift boyamadır. Akridin turuncusu boyası vital bir boyadır ve hem canlı hem de ölü hücreleri boyar. Etidyum bromür boyası ise sadece membran bütünlügünü kaybetmiş hücreleri boyar. Sağıklı hücreler homojen bir yeşil, erken apoptotik hücreler ise kromatin yoğunlaşması ve nükleer parçalanma dolayısıyla özellikle çekirdeklerinde parlak yeşil noktalar içerecektir. Geç apoptotik hücreler hem AT hem de EB içerdiğinden dolayı turuncu rengi alacaktır. Fakat nekrotik hücreler sağlıklı hücrelerin aksine yoğunlaşmış kromatin içerdiğinden farklı bir nükleer morfoloji ve boya yoğunluğuna sahip olduğundan bozuk şekilli kırmızı görünür (19). 6'lık plakalara ekilen hücreler $\mathrm{IC}_{50}$ altındaki dozlarda $(1-40 \mu \mathrm{M})$ tedavi uygulandıktan 24 saat sonra tripsin-EDTA ile kaldırıldı. 1xPBS ile yıkanan hücreler $+4^{\circ} \mathrm{C}^{\prime}$ de $500 \mathrm{xg}$ 'de 5 dakika santrifüj ardından süpernatant 
atıldı. Boş lamın üzerine $10 \mu \mathrm{L}$ hücre pelleti ve $10 \mu \mathrm{L}$ AT/EB solüsyonu $(100 \mu \mathrm{g} / \mathrm{mL} A T+100 \mu \mathrm{g} / \mathrm{mL}$ EB) eklenip lamel kapatıldı. Görüntüler floresans mikroskopta (Leica DM 1000, Solms, Almanya) değerlendirilip kaydedildi. Rastgele kaydedilen hücrelerde her konsantrasyonda 4 tekrar ve minimum 100 hücre sayıldı.

\section{istatistiksel Analiz}

Sonuçlar ortalama \pm standart sapma olarak verildi. Tüm deneylerdeki veriler, varyans analizleri (One-Vay ANOVA) kullanılarak istatistiksel anlamlıık açısından analiz edilmiştir. DADS ve DATS'ın hücre hatları üzerindeki $I_{50}$ değerleri, doğrusal olmayan regresyon analizi ile hesaplanmıştır. Tüm parametreler arasındaki ilişkiler Pearson korelasyon katsayısı ile analiz edilmiştir. $p<0,05$ değeri istatistiksel olarak anlamlı kabul edildi. Tüm istatistiksel analizler SPSS paket programı kullanılarak yapıldı (Windows için Sürüm 25, Şikago, ABD).

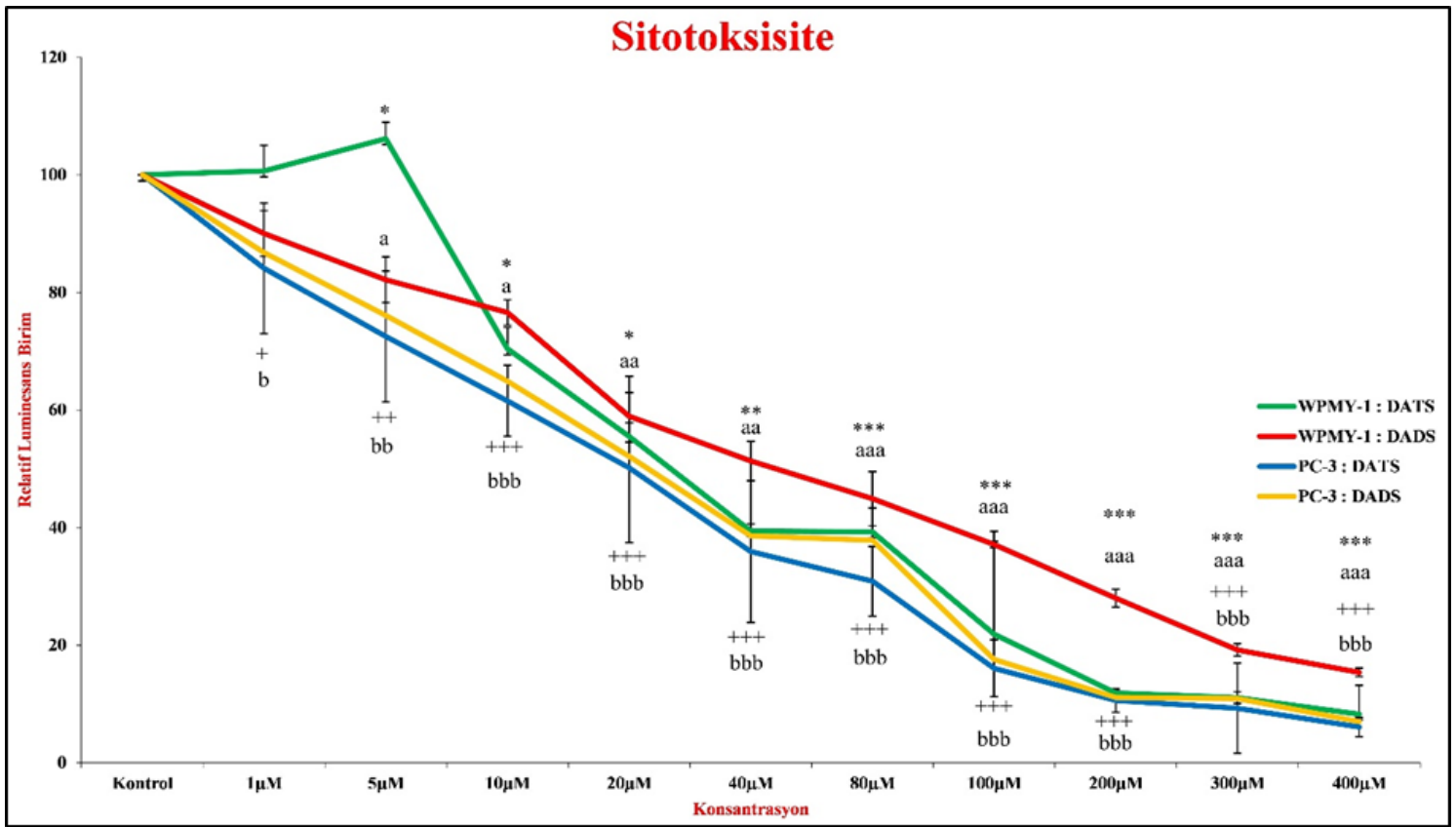

Şekil 1. DADS ve DATS'ın hücre canlıı̆ı üzerindeki etkisi.

PC-3 ve WPMY-1 hücrelerinde DADS ve DATS'ın farklı konsantrasyonları 24 saat inkübe edildi. Tüm sonuçlar kontrole (\% 0,1 DMSO) göre relatif olarak hesaplandı. Veriler dört bağımsız çalışmayı temsil etmektedir ve ortalama \pm standart sapma olarak ifade edilmiştir. WPMY-1 hücrelerinde DADS'daki farklılıklar, * $p<0,05 ;{ }^{* \star}$ $p<0,01,{ }^{* * \star} p<0,001 ;$ DATS'daki farkllıklar a $p<0,05$; aa $p<0,01$, aaa $p<0,001 ; P C-3$ hücrelerinde DADS'daki farkllıklar, ${ }^{b} p<0,05 ;{ }^{\text {bb }} p<0,01$, bbb $p<0,001 ; D A T S^{\prime} d a k i$ farklılıklar $+p<0,05 ;++p<0,01,+++p<0,001$ değerleri istatistiksel olarak anlamlı kabul edildi.

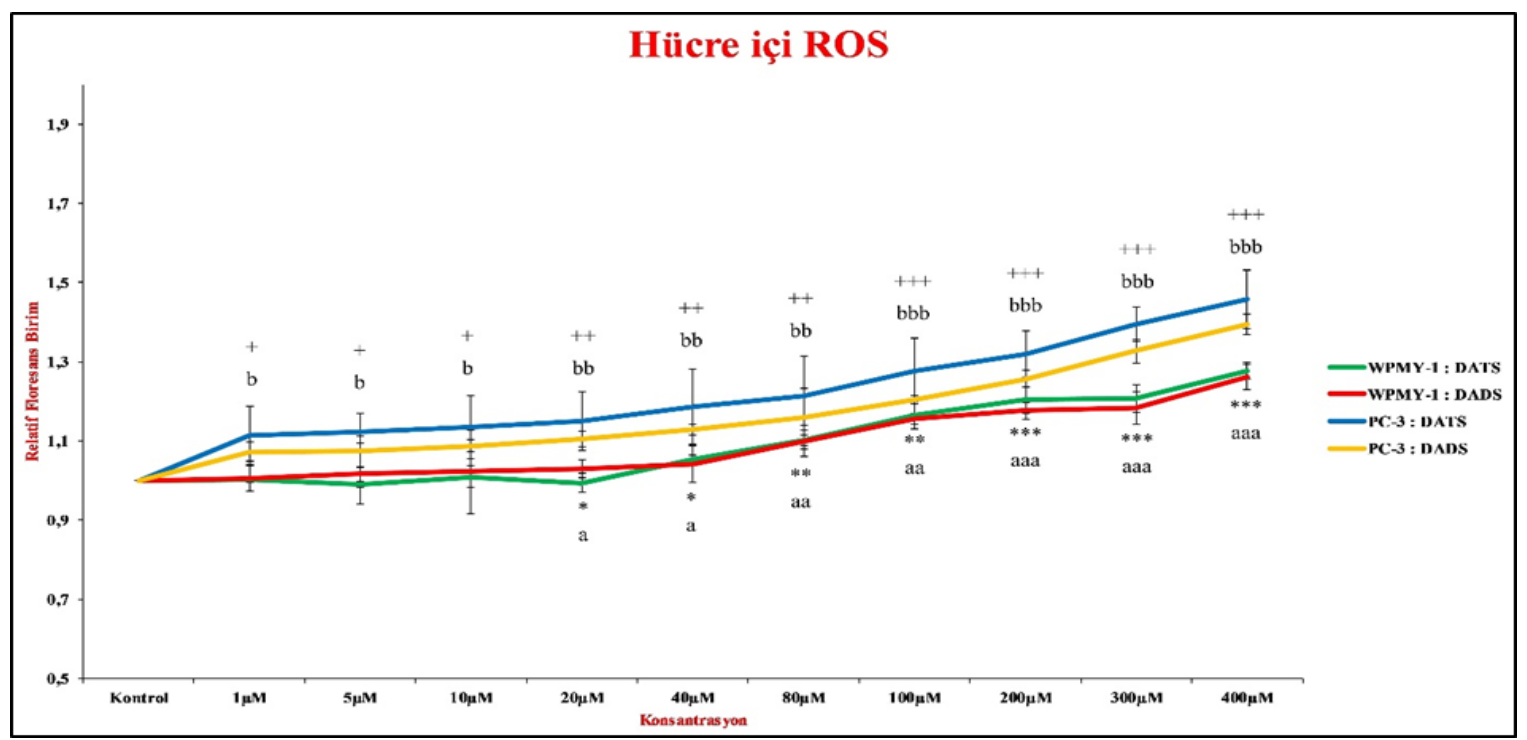

Şekil 2. DADS ve DATS'ın PC-3 ve WPMY-1 hücreleri üzerindeki hücre içi ROS düzeyine etkisi. DADS ve DATS ile hem sağıkı hem de kanser hücrelerinde hücre içi ROS düzeyleri artmıştır. Dozlar kontrole göre relatif olarak hesaplanıp ATP düzeyi ile normalize edilmiştir. Veriler dört bağımsız çalışmayı temsil etmektedir ve ortalama \pm standart sapma olarak ifade edilmiștir. WPMY-1 hücrelerinde DADS'daki farkllıklar, * $p<0,05 ;{ }^{* *} p<0,01,{ }^{* * *} p<0,001 ;$ DATS' daki farkllıklar a $p<0,05$; aa $p<0,01$, aaa $p<0,001 ; P C-3$ hücrelerinde DADS'daki farkllıklar, $b p<0,05 ; b b p<0,01, b b b p<0,001 ;$ DATS' daki farklliklar $+p<0,05 ;++p<0,01$, $+++p<0,001$ değerleri istatistiksel olarak anlamlı kabul edildi. 


\section{Bulgular}

\section{DADS ve DATS'ın prostat kanser ve sağlıklı hücresin- deki sitotoksisitesi}

DADS ve DATS'ın prostat kanser (PC-3) ve sağlıklı prostat epitel (WPMY-1) hücrelerindeki 24 saatlik inkübasyonunun canlılık üzerine etkisi luminometrik ATP canlılık deneyi ile değerlendirildi. Deneylerden önce PC-3 ve WPMY-1 hücrelerinin canlılı̆ı̆ \%95'in üzerindeydi. DADS ve DATS'ın inkübasyonu hücre canlılığını istatistiksel olarak anlamlı düzeyde azalttı $(p<0,001)$. Artan dozlardaki sonuçlar kontrole (\%0,1 DMSO) göre relatif olarak hesaplandı. Doza bağımlı olarak artan konsantrasyonlarda sitotoksisite anlamlı derecede artmıştır (Şekil 1). DADS ve DATS'ın kanser ve sağlıklı hücrelerde $I C_{50}$ dozları doz-cevap eğrisinden hesaplandı (PC-3 için DADS: 22,96 $\mu \mathrm{M}$, DATS: $20,24 \mu \mathrm{M}$; WPMY-1 için DADS: $64,89 \mu \mathrm{M}$, DATS: $27,21 \mu \mathrm{M}$ ). Bulunan bu $\mathrm{IC}_{50}$ dozlarının altındaki dozlarda hücre içi kalsiyum, glutatyon, mitokondriyal membran potansiyeli ölçümleri ile, apoptoz ve genotoksisite analizleri yapıldı.

\section{DADS ve DATS'ın hücre içi ROS aktivitesine etkisi}

Prostat kanser ve sağlıklı hücrelerinde, hücre içi ROS düzeylerini incelemek için floresans özelliği olan $\mathrm{H}_{2}$ DCF-DA probu kullanıldı. 24 saatlik DADS ve DATS inkübasyonu kanser ve sağlıklı hücrelerde hücre içi ROS düzeylerini doza bağımlı olarak istatistiksel anlamlı olarak artmıştır ( $p$ $<0.001)$. Kanser hücrelerindeki relatif olarak artan hücre içi ROS miktarı sağlıklı hücrelere göre daha yüksek bulundu (Şekil 2).

\section{Hücre içi kalsiyum düzeyleri}

Kalsiyum çok çeşitli hücresel mekanizmaları etkileyen önemli bir ikincil habercidir. Hücre içinde serbest olan yada konsantrasyonu artan $\mathrm{Ca}^{2+}$ mitokondri tarafından alındığında apoptotik mekanizmalar indüklenir. DADS ve DATS'ın kanser ve sağlıklı hücrelerde hücre içi kalsiyum düzeylerine etkisini Fura-2AM floresans probu ile değerlendirildi. Artan DADS ve DATS konsantrasyonları PC-3 ve WMPY-1 hücrelerinde $\mathrm{Ca}^{2+}$ konsantrasyonlarını doza bağımlı olarak arttırdı. Kalsiyum düzeyleri kanser hücrelerinde sağıklı hücrelere göre doza bağımlı olarak istatistiksel anlamlı $(p<0,001)$ ve yüksek bulundu (Şekil 3).

\section{Mitokondriyal Membran Potansiyelindeki Değişimler}

Mitokondriyal apoptotik yol hem kanser hem de sağlıklı hücrelerde apoptotik indüksiyonun altında yatan mekanizmaları göstermek için araştırıldı. Azalan MMP apoptoza yol açmaktadır. MMP'yi değerlendirmek için DADS ve DATS'ın 24 saatlik hücrelerdeki inkübasyonunun ardından DiOC6(3) floresans probu kullanılarak doza bağımlı olarak istatistiksel olarak anlamlı azalma $(p<0,05)$ gözlenmiştir (Şekil 4).

\section{Hücre içi glutatyon}

DADS ve DATS insan prostat kanser hücreleri ve sağlıklı prostat epitel hücrelerinde GSH düzeylerini düşürmüştür. 24 saatlik DADS ve DATS inkübasyonu sonrasında GSH düzeyleri istatistiksel olarak anlamlı bir şekilde düştüğü $(p<0,05)$ bulunmuştur.

\section{DNA Hasarı}

DADS ve DATS'ın IC ${ }_{50}$ dozlarının altındaki farklı konsantrasyonları, 24 saat boyunca kanser ve sağlıklı hücrelerdeki genotoksik hasarını değerlendirmek için comet assay metodu ile çalışıldı. Hasarlı DNA'lar çekirdekleri parlak ve kuyruklu yıldız özelliğindeydi, hasarsız DNA'lar ise yuvarlak ve büyüktü. Her konsantrasyonda en az 100 hücre görüntülenip kaydedildi. Hasar derecesi \% kuyruk yoğunluğu olarak verildi. Artan DADS ve DATS konsantrasyonları DNA hasarını istatistiksel olarak artırmışı̧ı (Şekil 6$),(p<0,001)$. Artan hasarla oluşan DNA kuyruklu yıldız görüntülerinin mikrografları şekil 7'de sunulmuştır.

\section{DADS ve DATS apoptoza etkisi}

Apoptotik defektler/bozukluklar tümör oluşumu ve tedaviye direnç açısından kritik öneme sahiptir. DADS ve DATS'ın $\mathrm{IC}_{50}$ dozları altındaki farklı konsantrasyonları 24 saat inkübasyon sonrasında kanser ve sağlıklı hücrelerde apoptoza neden olup olmadığını açıklığa kavuşturmak için AT/EB çift boyası kullanılarak floresans mikroskopta görüntü alındı. Hücrelerde doza bağlı bir şekilde apoptozun arttığı, kanser hücrelerindeki apoptoz oranının sağlıklı hücrelere göre daha yüksek olduğu bulundu (Şekil 8). Konsantrasyon arttıkça \% apoptoz miktarı istatistiksel olarak anlamlı düzeyde artmıştı $(p<0,001)$. Her dozda en az 100 hücre sayılarak kaydedilip yarı kantitatif apoptotik hücre sayısı hesaplandı (Şekil 9).

DADS'ın PC-3 kanser hücresinde ve WPMY-1 sağlıkı hücresinde sırasıyla doz ile canlılık $(r=-0,927, p=0,008$; $r=-$ $0,933, p=0,007)$, hücre içi ROS $(r=0,816, p=0,048$; $r=0,946, p=0,004)$, DNA Hasarı $(r=0,918, p=0,010$; $r=0,914, p=0,011)$, apoptoz $(r=0,836, p=0,038 ; r=0,883$, $p=0,020), G S H(r=-0,907, p=0,013 ; r=-0,850, p=0,032)$, MMP $(r=-0,859, p=-0,028 ; r=-0,775, p=0,070)$ ve kalsiyum $(r=0,834, p=0,039 ; r=0,863, p=0,027)$ arasında istatistiksel olarak anlamlı güçlü korelasyonlar bulunmuştur.

DATS'ın PC-3 kanser hücresinde ve WPMY-1 sağlıklı hücresinde sırasıyla doz ile canllık $(r=-0,915, p=0,011 ; r=-$ $0,927, p=0,008)$, hücre içi ROS $(r=0,740, p=0,093$; $r=0,817, p=0,047)$, DNA Hasarı $(r=0,870, p=0,024$; $r=0,917, p=0,010)$, apoptoz $(r=0,855, p=0,030 ; r=0,884$, $p=0,019)$, GSH $(r=-0,909, p=0,012 ; r=-0,807, p 0,052)$, MMP $(r=-0,765, p=0,076 ; r=-0,857, p=0,029)$ ve kalsiyum $(r=0,810, p=0,051 ; r=0,826, p=0,043)$ arasında istatistiksel olarak anlamlı korelasyonlar tespit edilmiştir. 


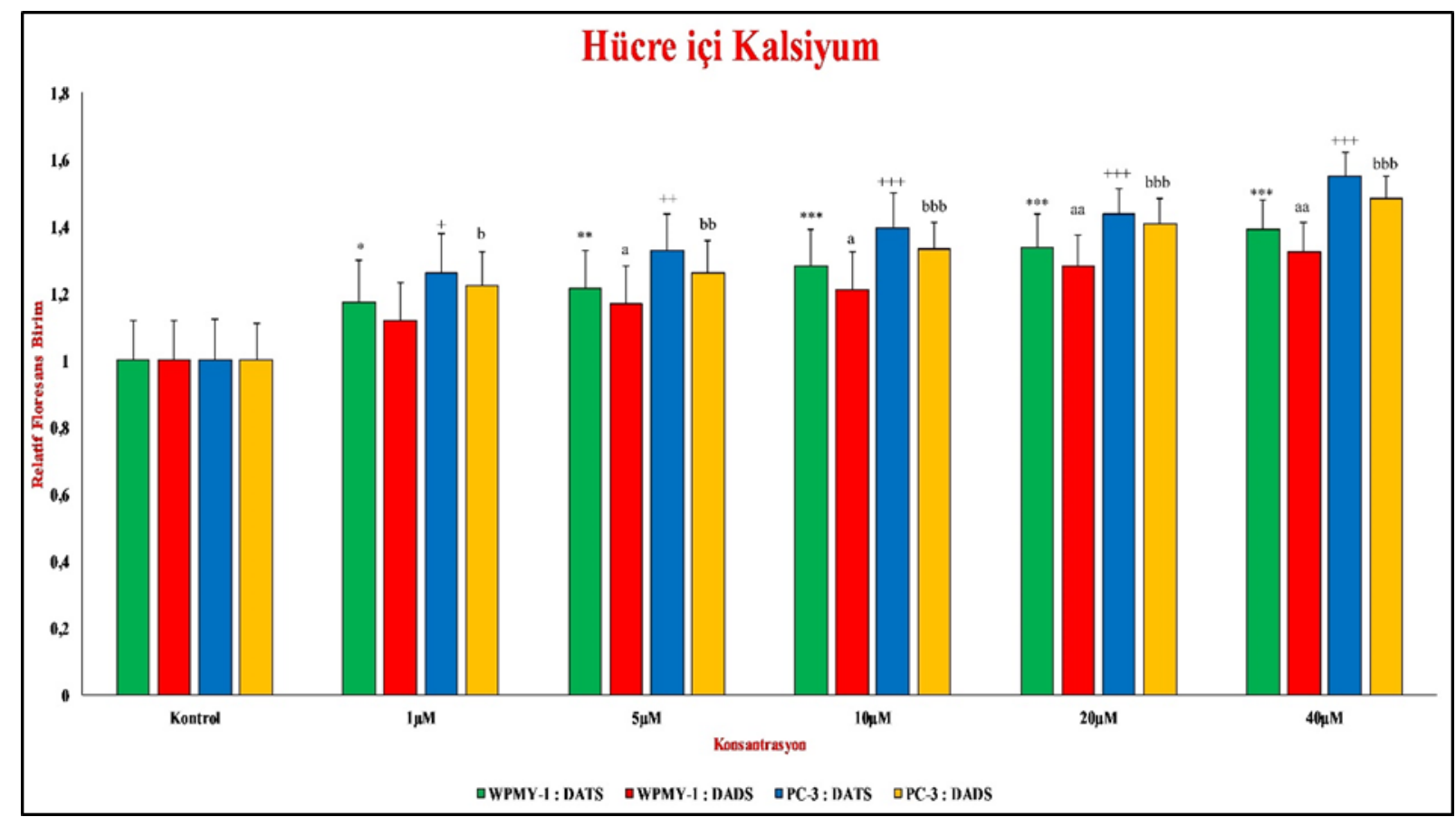

Şekil 3. DADS ve DATS'ın PC-3 ve WPMY-1 hücreleri üzerindeki hücre içi kalsiyum düzeyine etkisi.

DADS ve DATS ile hem sağıklı hem de kanser hücrelerinde hücre içi Ca2+ düzeyleri artmıştır. Dozlar kontrole göre relatif olarak hesaplanıp ATP düzeyi ile normalize edilmiștir. Veriler dört bağımsız çalıșmayı temsil etmektedir ve ortalama \pm standart sapma olarak ifade edilmiștir. WPMY-1 hücrelerinde DADS'daki farklılıklar, ${ }^{*} p<0,05$; ${ }^{* *} p<0,01,{ }^{* * *} p<0,001$; DATS'daki farkllıklar a $p<0,05 ;$ aa $p<0,01$, aaa $p<0,001 ;$ PC-3 hücrelerinde DADS'daki farklılıklar, b $p<0,05 ; b b p<0,01$, bbb $p<0,001 ;$ DATS'daki farklılıklar $+p<0,05 ;++p<0,01,+++p<0,001$ değerleri istatistiksel olarak anlamlı kabul edildi.

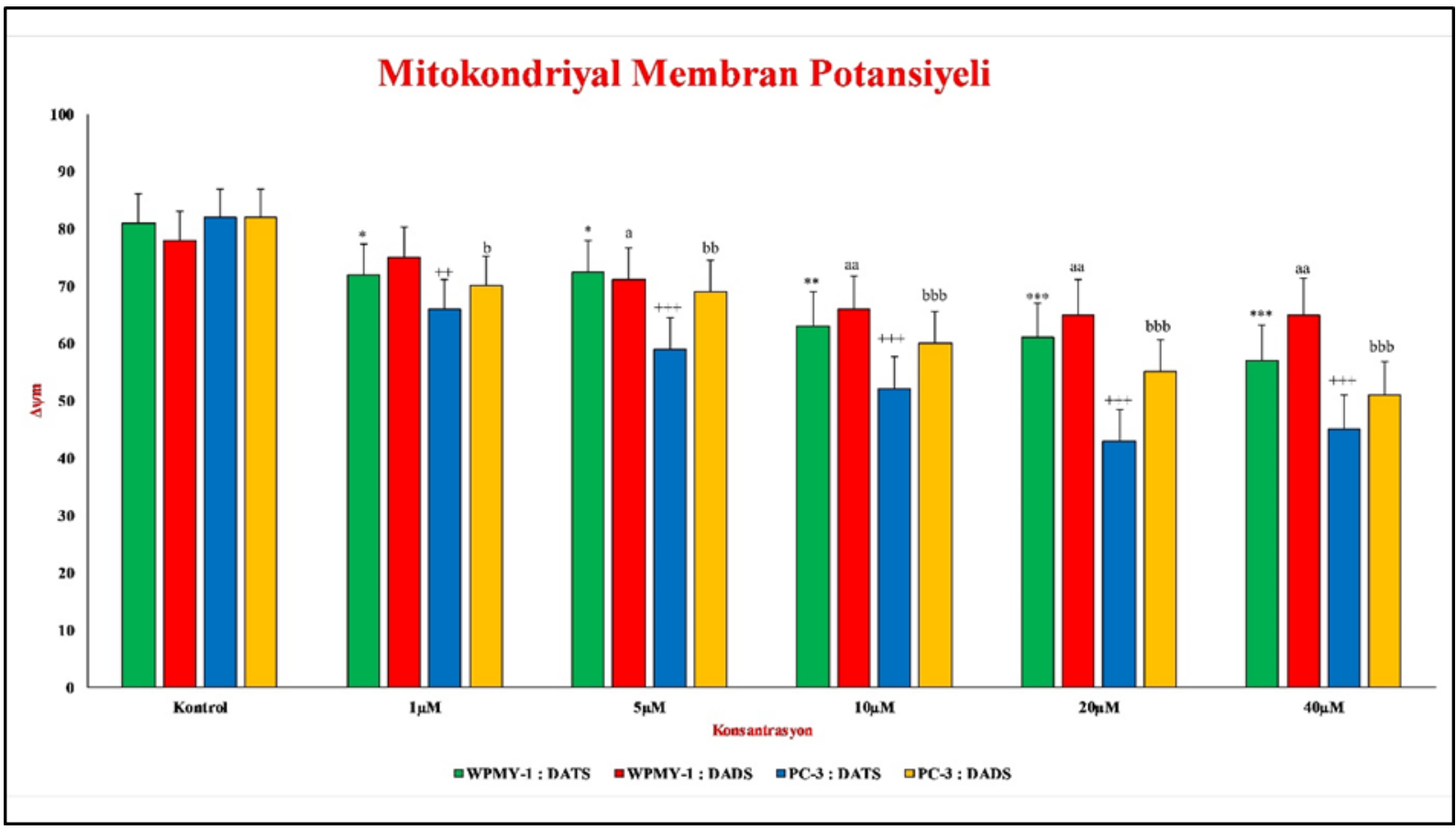

Şekil 4. DADS ve DATS'ın PC-3 ve WPMY-1 hücreleri üzerindeki mitokondriyal membran potansiyeli üzerine düzeyine etkisi.

DADS ve DATS ile hem sağıkı hem de kanser hücrelerinde mitokondriyal membran potansiyellerini azaltmıştır. Dozlar kontrole göre relatif olarak hesaplanıp ATP düzeyi ile normalize edilmişstir. Veriler dört bağımsız çalışmayı temsil etmektedir ve ortalama \pm standart sapma olarak ifade edilmiştir. WPMY-1 hücrelerinde DADS'daki farkllıklar, " $p<0,05 ;{ }^{* *} p<0,01,{ }^{* * *} p<0,001$; DATS'daki farkllıklar a $p<0,05$; aa $p<0,01$, aaa $p<0,001 ; P C-3$ hücrelerinde DADS'daki farkllıklar, b $p<0,05 ; b b \quad p<0,01$, $b b b$ p $<0,001 ;$ DATS'daki farkllıklar $+p<0,05 ;++p<0,01,+++p<0,001$ değerleri istatistiksel olarak anlamlı kabul edildi. 


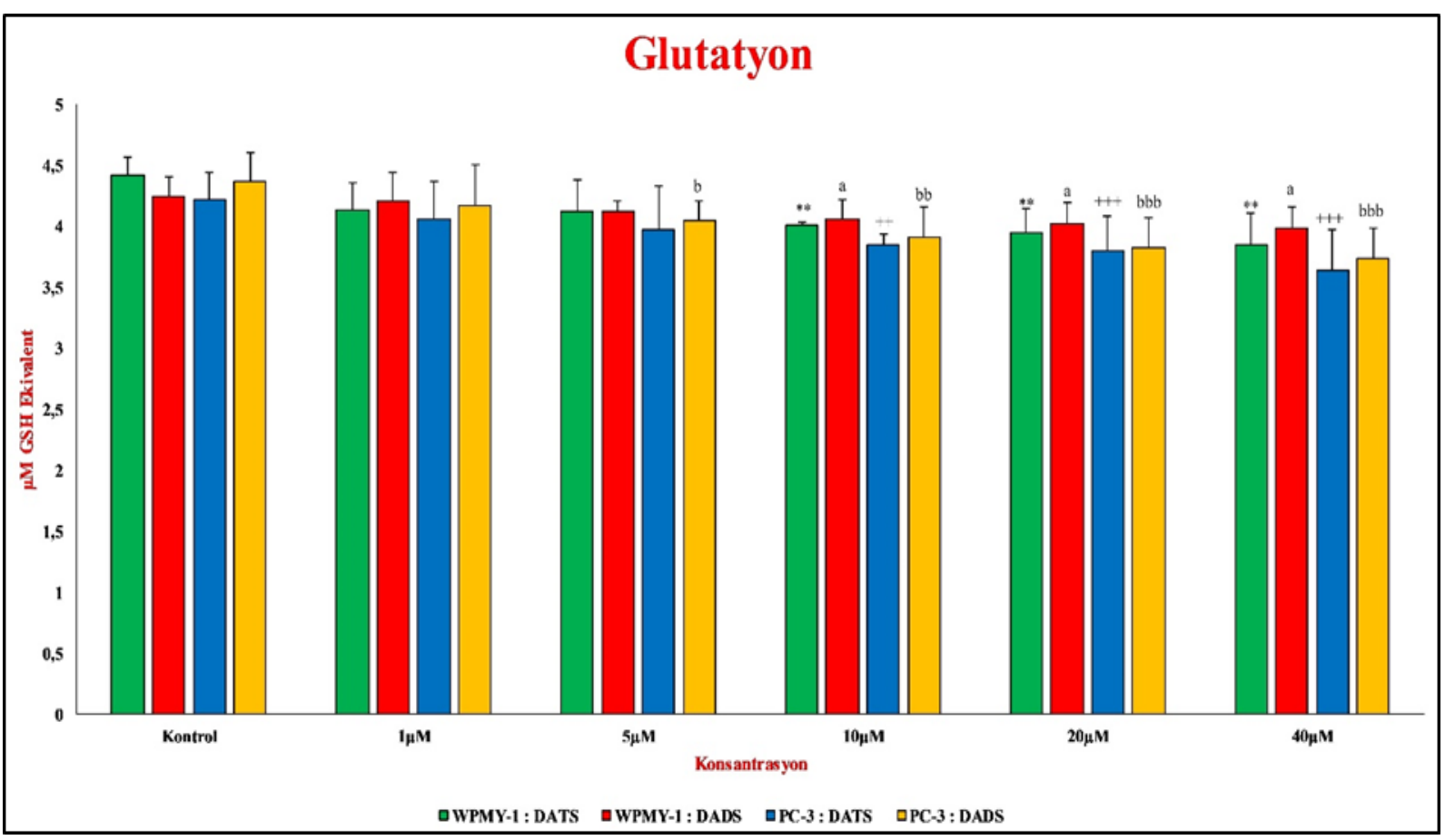

Sekil 5. DADS ve DATS'ın PC-3 ve WPMY-1 hücreleri üzerindeki glutatyon düzeyleri üzerine etkisi.

DADS ve DATS ile hem sağıklı hem de kanser hücrelerinde glutatyon düzeylerini azaltımıştır. Veriler dört bağıısıı çalışmayı temsil etmektedir ve ortalama \pm standart sapma olarak ifade edilmistir. WPMY-1 hücrelerinde DADS'daki farkllıklar, ${ }^{*} p<0,05$; ${ }^{* *} p<0,01,{ }^{* * *} p<0,001$; DATS'daki farkllıklar a $p<0,05$; aa $p<0,01$, aaa $p<0,001$ : $P C$-3 hücrelerinde DADS'daki farkllıklar, $b \quad p<0,05 ; b b p<0,01, b b b \quad p<0,001$; DATS'daki farkllıklar + $p<0,05 ;++p<0,01,+++p<0,001$ değerleri istatistiksel olarak anlamlı kabul edildi.

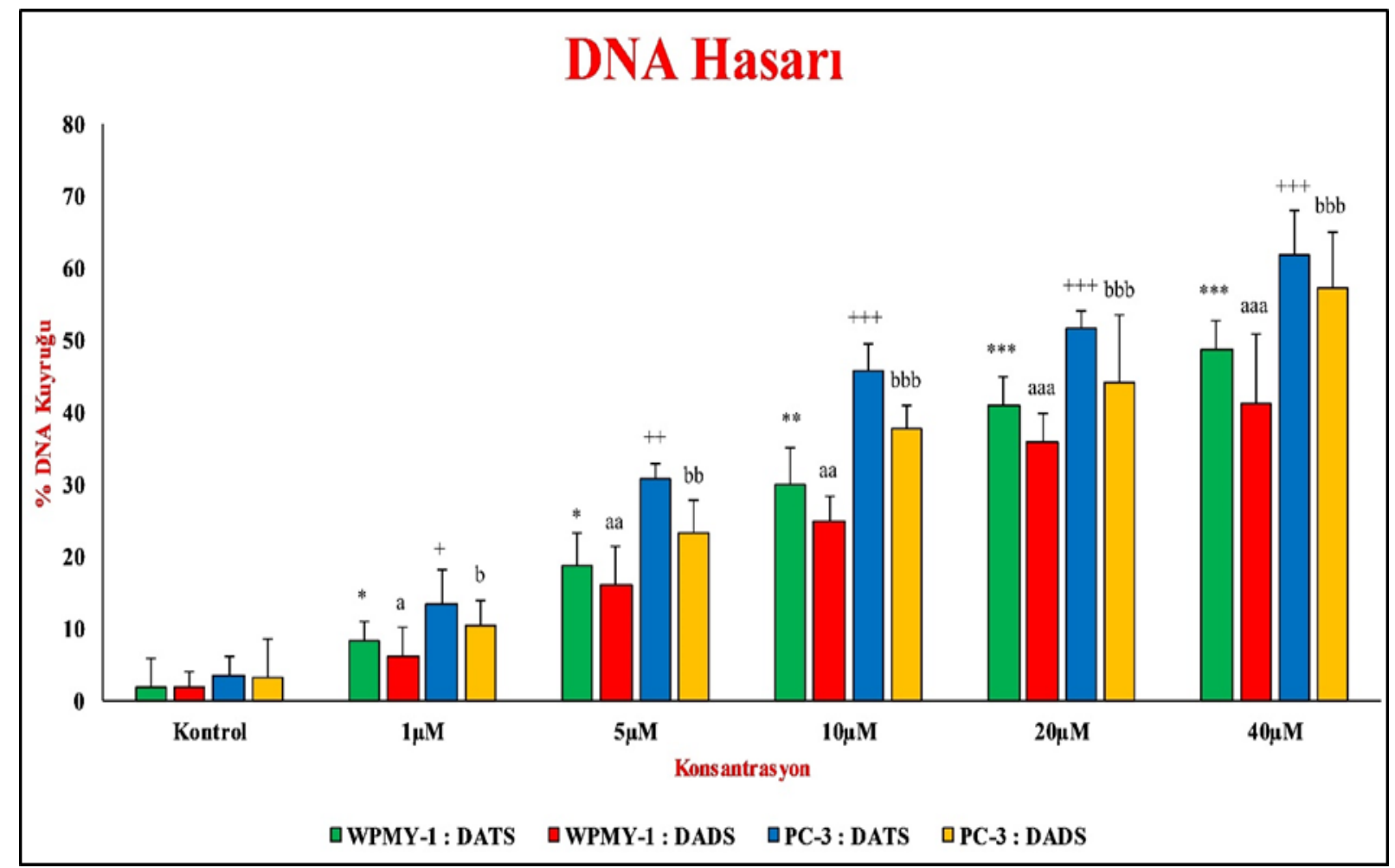

Şekil 6. DADS ve DATS'ın PC-3 ve WPMY-1 hücreleri üzerindeki DNA hasarına etkisi.

DADS ve DATS ile hem sağlıkı hem de kanser hücrelerinde DNA hasarını yani genotoksisiteyi arttırmıştı. Sonuçlar \% kuyruk yoğunluğu olarak verilip, ortalama \pm standart sapma olarak ifade edilmiștir. WPMY-1 hücrelerinde DADS'daki farkllıklar, * ${ }^{*}<0,05 ;{ }^{* *} p<0,01$, ${ }^{* * *} p<0,001 ;$ DATS'daki farkllıklar a $p<0,05$; aa $p<0,01$, aaa $p<0,001 ; P C-3$ hücrelerinde DADS'daki farkllıklar, b $p<0,05 ; b b p<0,01, b b b \quad p<0,001 ;$ DATS'daki farklliklar $+p<0,05 ;++p<0,01,+++p<0,001$ değerleri istatistiksel olarak anlamlı kabul edildi. 


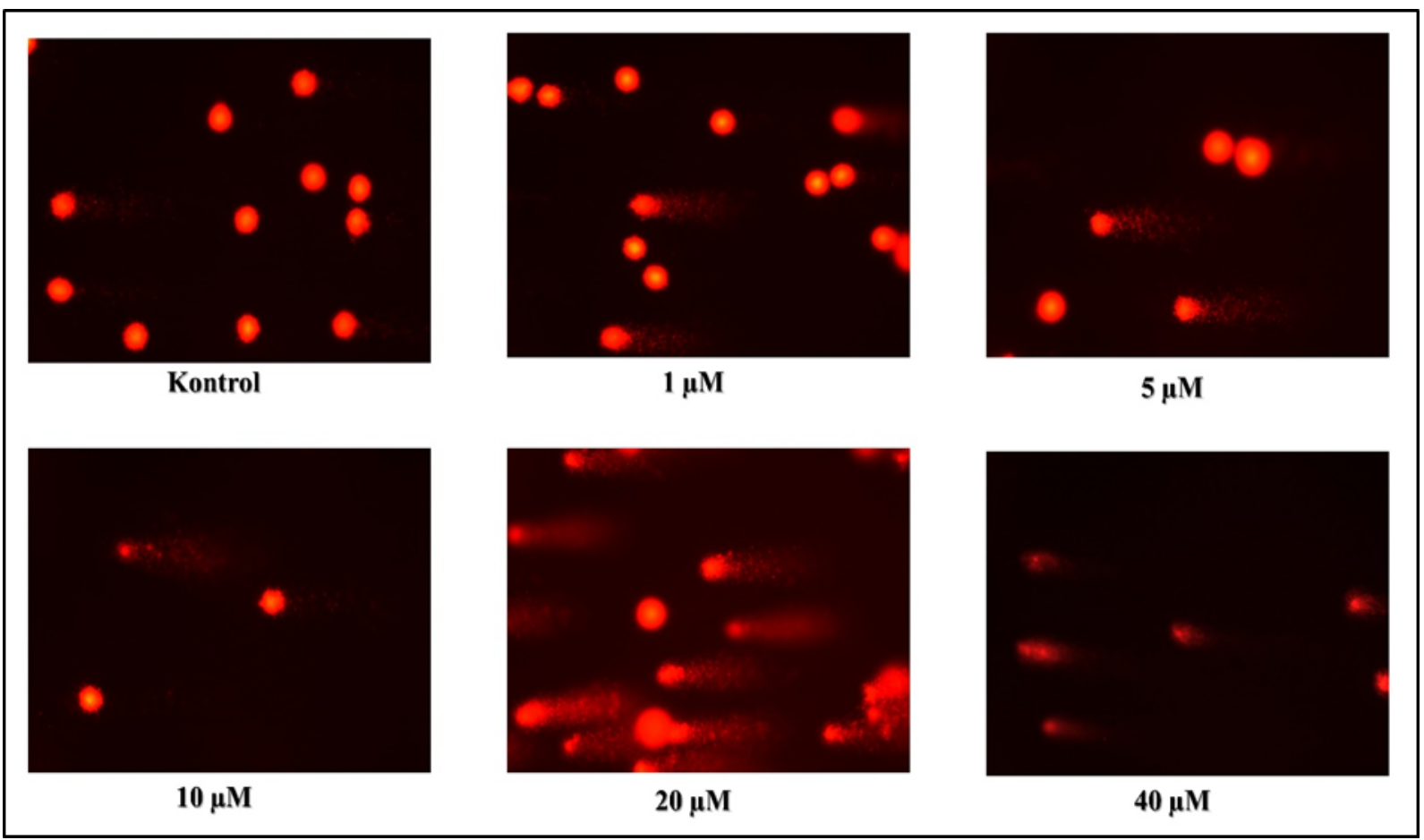

Sekil 7. DATS'ın PC-3 hücresi üzerindeki farklı konsantrasyonlarının DNA hasarı üzerine etkisi.

Hasar sonrası oluşan DNA'daki kuyruklu yıldız görüntüsü doz arttıkça artmıştır.

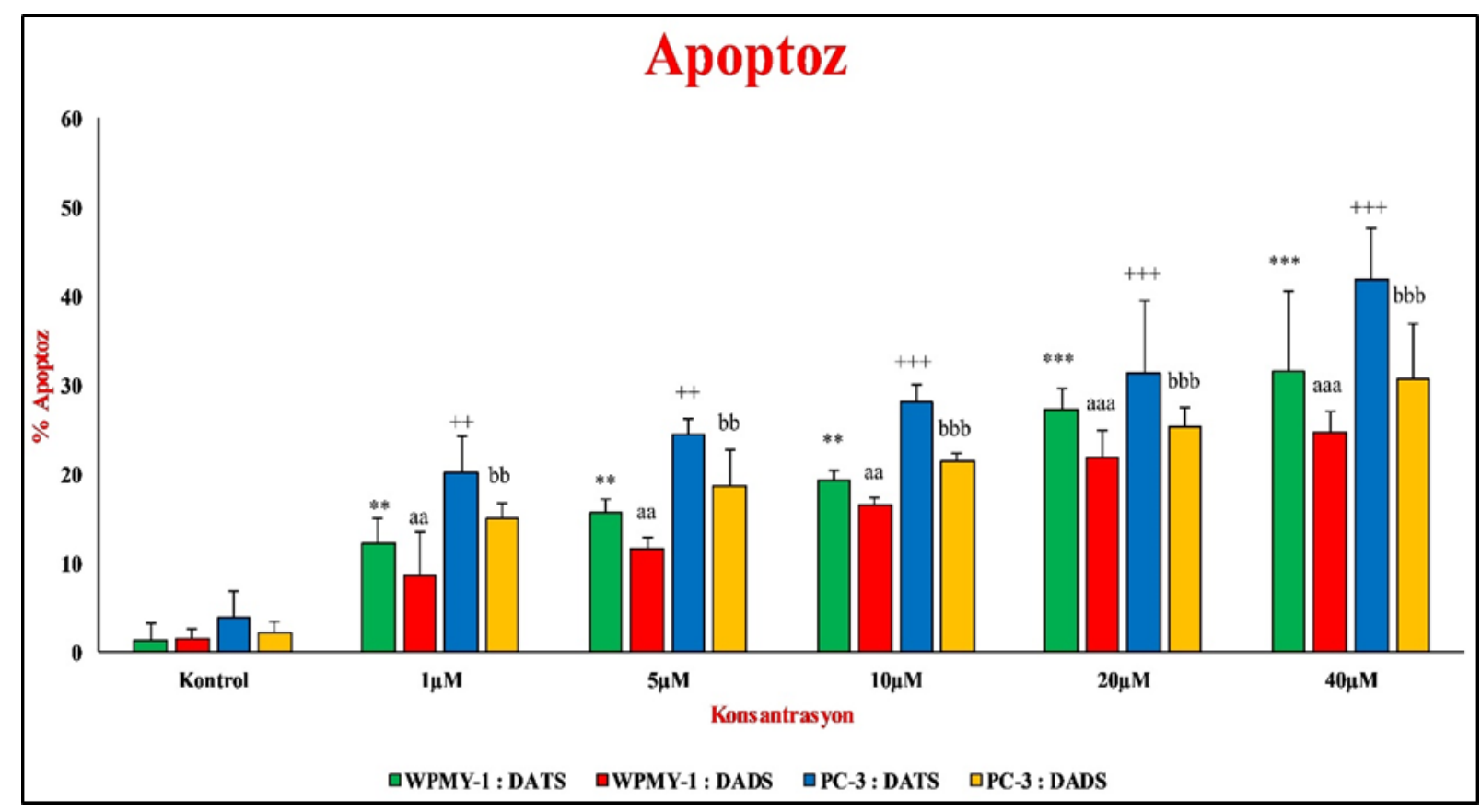

Şekil 8. DADS ve DATS'ın PC-3 ve WPMY-1 hücreleri üzerindeki apoptoz üzerine etkisi. DADS ve DATS ile hem sağlıkı hem de kanser hücrelerinde apoptozu indüklemiştir. Yarıkantitatif sayılan hücreler ortalama \pm standart sapma olarak ifade edilmiştir. WPMY-1 hücrelerinde DADS'daki farklılıklar, * $p<0,05 ;{ }^{* \star} p<0,01,{ }^{* \star *} p<0,001$; DATS'daki farkllıklar a $p<0,05$; aa $p<0,01$, aaa $p<0,001 ; P C-3$ hücrelerinde DADS'daki farklllklar, b $p<0,05 ; b b p<0,01, b b b p<0,001$; DATS'daki farklılıklar $+p<0,05 ;++p<0,01,+++p<0,001$ değerleri istatistiksel olarak anlamlı kabul edildi. 


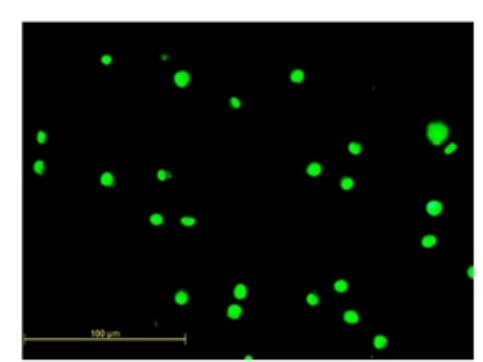

Kontrol

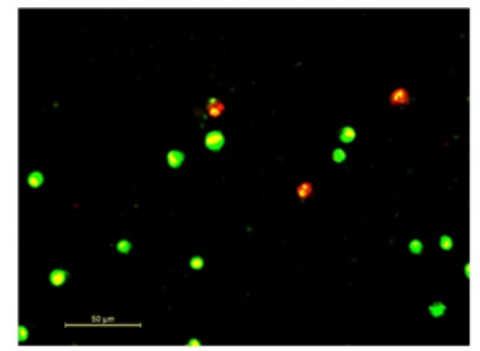

$10 \mu \mathrm{M}$

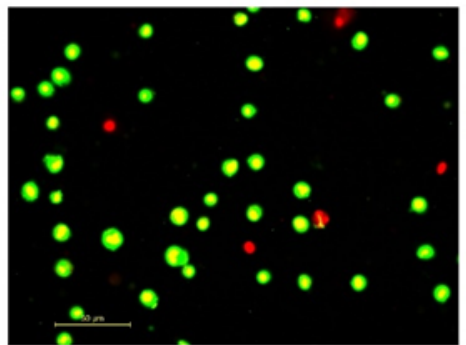

$1 \mu \mathrm{M}$

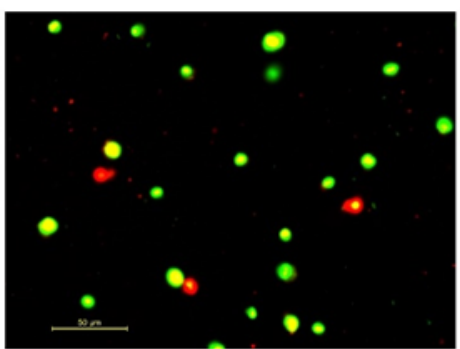

$20 \mu \mathrm{M}$

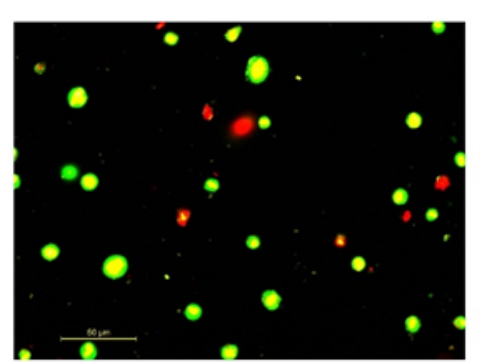

$5 \mu \mathrm{M}$

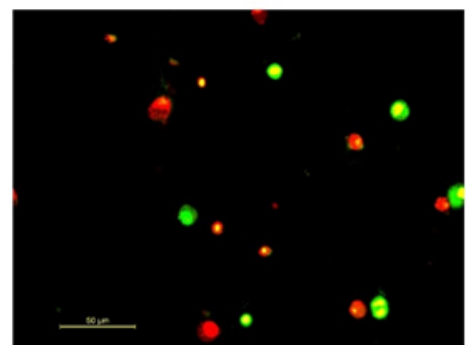

$40 \mu \mathrm{M}$

Şekil 9. DATS'ın PC-3 hücresi üzerindeki farklı konsantrasyonlarının apoptoz üzerine etkisi.

24 saat sonra AT/EB çift boyası ile boyanan hücrelerde sağılılı canlı hücreler düzgün yapılı ve yeşil; apoptotik hücreler yoğunlaşmış kromatin ve parçalanmış çekirdek ile sarı-turuncu; nekrotik hücreler ise kırmızı renkte görünmektedir.

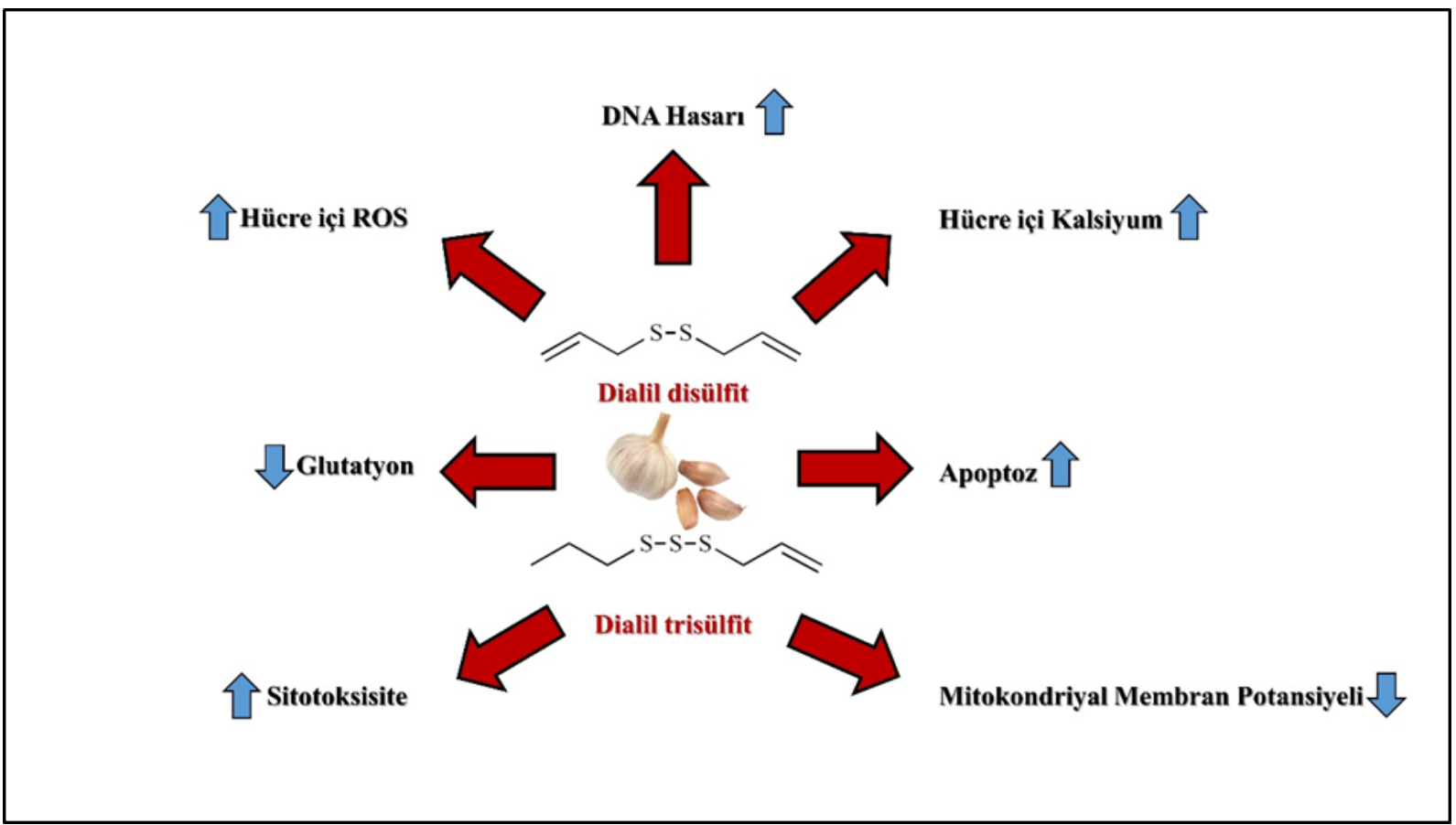

Şekil 10. DADS ve DATS'ın PC-3 ve WPMY-1 hücreleri üzerindeki etkisi (Grafik Özet)

\section{Tartışma}

Prostat kanseri, en sık görülen kanser türlerinden biridir ve özellikle sanayileşmiş ülkelerde erkeklerde ikinci önde gelen ölüm nedenidir. Tedavi stratejilerinde cerrahi, hormon tedavisi ve kemoterapi olmasına rağmen bir süre sonra ilaçlara direnç gelişebilmektedir (20). Ayrıca, kanser tedavisi için birçok farklı kemoterapötik ilaç kullanılmakta fakat bütün bu ilaçlar sadece kanser hücrelerine değil sağ|ıklı hücrelere zarar vermektedir. Bu nedenle, daha etkili ve daha selektif yeni antitümör ajan arayışı giderek artan hızda sürmektedir. Son yıllarda kanser tedavisinde doğal bitkisel ürünler ve etken maddeleri ilgi odağı olmuştur (21). Çok sayıda çalışma sarımsağın etken maddesi olan DADS ve DATS'ın çeşitli kanser hücreleri üzerinde sitotoksik, ve apoptotik etkiler gösterdiği bildirmiştir (7). Çalışmamızda DADS ve DATS'ın hücre içi ROS'u ve kalsiyumu artırıp, 
glutatyon ve MMP'yi düşürerek hem prostat kanser hem de prostat sağlıklı epitel hücrelerinde sitotoksisiteyi genotoksisiteyi ve apoptozu indüklediğini gösterdik. Bu etken maddelerin kanser hücrelerini sağlıklı hücrelere göre daha çok etkilediği ve DATS'ın DADS'a göre daha çok etkili olduğunu tespit ettik. Sarımsağın ekstraktı ve etken maddeleri ile kanser hücrelerini inhibe eden bir çok çalışma yapılmıştır. Özellikle DADS ve DATS ile bir çok kanser türlerinde çalışıımasına ve etkisi gösterilmesine rağmen sağlıklı hücre ile kanser hücresinin sonuçları bir arada değerlendirilmemiştir. DADS ve DATS her ne kadar bitkisel kökenli etken maddeler olsa da sonuçlarımızdan da görüleceği gibi yüksek dozlarda sitotoksik etkileri vardır. Hücre canlıı̆̆ı ile hücre içi ROS, DNA hasarı ve apoptoz arasında güçlü negatif korelasyonun bulunması, bize kanser hücrelerinin ölümünde etken maddelerin artan dozları ile birlikte artan hücre içi ROS üretiminin etkili olduğunu göstermektedir. Çalışmamızda DADS ve DATS artan konsantrasyonlarda $(1-400 \mu \mathrm{M})$ prostat kanser ve sağ|ıkı prostat epitel hücreleri üzerine anti-proliferatif etki gösterdiğini, ancak etkinin kanser hücrelerinde sağlıkı hücrelere göre daha fazla olduğunu gördük. Sağlıklı hücrelerde hücre içi hücre içi ROS artış seviyeleri de kanser hücrelerine göre daha düşük bulundu. Kanser hücrelerinde metabolik özellikleri nedeniyle, bazal ROS seviyelerinin sağıklı hücrelere göre daha yüksek olduğu bilinmektedir (22). Dolayısı ile, kanser hücrelerinde etken maddelerin pro-oksidan aktivite ile oluşturdukları ROS ve bazal ROS'un kümülatif etkisinin neden olduğu DNA hasarı ve apoptoza bağlı hücre ölümünün sağıklı hücrelere göre daha fazla olması beklenebilir. Yapılan diğer çalışmalarda DADS insan gastrik kanser hücrelerinde (MGC803) ERK1/2 yolağını inhibe ederek (23), insan kolon kanser hücresi olan HCT-15'te G2/M fazını durdurarak ve ERK fosforilasyonunu inhibe ederek (24), Colo 205 kolon kanser hücresinde ERK1/2, p38, MMP2 ve MMP9'u inhibe ederek (25), yine bir başka insan kolon kanseri hücreleri olan Caco-2 ve HT-29'da HDAC inhibisyonu, histon asetilasyonu, CDKN1A ve p21 aktivasyonu ile (26), SW480 insan kolon kanseri ve NIH3T3 fare fibroblast hücrelerinde G2/M fazını durdurarak (27) inhibisyon sağladığı gösterilmiştir. DATS ise insan prostat kanser hücrelerinde G2/M fazını durdurmuş, Cdc25C'yi hiperfosforilasyona uğratmış ve SiklinB1 kinazı ve colo 205 kolon kanser hücre hattında ERK1/2 yolağını durdurarak kanser hücrelerini inhibe etmiştir (25). Çalışmamızda sitotoksik aktiviteyi en hassas gösteren test olan luminometrik ATP hücre canlılığı deneyi yaparak gösterdik. DADS ve DATS kanser ve sağlıklı hücrelerde doza bağlı sitotoksisiteyi arttırdı. Prostat kanser hücrelerindeki IC ${ }_{50}$ DADS: $22,96 \mu \mathrm{M}$ ve DATS: $20,24 \mu \mathrm{M}$ ile prostat epitel hücrelerindeki IC ${ }_{50}$ DADS: $64,89 \mu \mathrm{M}$, DATS: $27,21 \mu \mathrm{M}$ bulunarak bu maddelerin kanser hücrelerinde sağlık hücrelere göre daha çok etki ettiğini gösterdik.

Yapılan in vitro ve in vivo çalışmalar DADS ve DATS'ın kanser hücrelerine karşı farklı mekanizmaları kullanarak etkili olduğunu göstermiş̧tir (7). Bu mekanizmalardan biri de hücre içi ROS aktivitesidir. Organosülfür bileşikler olan DADS ve DATS düşük konsantrasyonlarda antioksidan özellik gösterirler ve oksidatif stresi ve hücre içi ROS'u inhibe ederler (28). Yüksek konsantrasyondaki DADS ve DATS hücrede artan hücre içi ROS üretimi ölüm reseptörü ve mitokondriyal yol ile apoptoza neden olabilir (29). Antioksidan bileşiklerin dozlarına göre antioksidatif/prooksidatif etki gösterdiği çeşitli mekanizmaları vardır. Kanser hücrelerinde antiproliferatif/sitotoksik aktivitesinde prooksidan etki sorumludur ve hücre ölümünü modüle etmek için anahtar sinyal görevi görür (30). Kanser hücrelerinde üretilen hücre içi ROS miktarı sağlıklı hücrelere göre yüksektir (22). Çalışmamızda relatif olarak kanser hücrelerindeki üretilen hücre içi ROS miktarı sağlıkı hücrelere göre daha yüksek bulunmuştur. Beklenildiği gibi DADS ve DATS doza bağımlı bir şekilde hücre içi ROS miktarını istatistiksel olarak anlamlı bir şekilde artırmıştır. Verilerimiz DADS ve DATS'ın diğer kanser hücrelerindeki hücre içi ROS artışı ile benzer çıkmıştır (31). Bu sebeple DADS ve DATS'ın 24 saatlik inkübasyonu ardından artan hücre içi ROS'un prostat kanser hücrelerindeki kümülatif etkisi sağlıklı prostat epitel hücrelerinden daha çok sitotoksisiteye neden olmuştur. Artan hücre içi ROS ile hücre canlılı̆̆ arasında hem sağlıklı hem de kanser prostat hücrelerinde güçlü bir negatif korelasyon vardır. Tüm bu sonuçlar ışığında oluşan sitotoksisite DADS ve DATS'ın prooksidan aktivitesinden kaynaklandığını göstermektedir. Normal fizyolojik koşullarda hüçre içi ROS seviyesinin korunması redoks potansiyeli ve hücre proliferasyonu için önemlidir. Yüksek ROS seviyesi başta DNA olmak üzere lipitlere ve proteinlere hasar verebilir ve apoptotik kaskadı başlatabilir (32).

Hücre içi kalsiyum $\left(\mathrm{Ca}^{2+}\right)$ homeostazı bir çok hücresel fonksiyonu kontrol eden sinyal mekanizmalarından biridir. Sitozolik $\mathrm{Ca}^{2+}$ konsantrasyonları, hücre zarından veya özel iyon kanalları yoluyla endoplazmik retikulumdan $\mathrm{Ca}^{2+}$ iyonlarına bağlıdır ve değişimlere karşı hassastır (33). Hücrelerde artan $\mathrm{Ca}^{2+}$ konsantrasyonları proapoptotik mekanizmayı tetikler (34). Çalışmamızdaki verilerde literatürde DADS ve DATS' In inkübasyonunda daha önce gösterilmemiş olan relatif olarak sağlıkı ve kanser hücrelerinde hücre içi $\mathrm{Ca}^{2+}$ düzeylerinin doza bağlı olarak arttığı gösterilmiştir. Artan $\mathrm{Ca}^{2+}$ düzeyleri ile apoptoz arasında güçlü bir pozitif korelasyon olduğunu gösterdik.

Mitokondriyal disfonksiyonun apoptozu indüklediği ve apoptotik yolağın merkezi olduğu ileri sürülmüştür (35). Çalışmamızda DADS ve DATS doza bağımlı bir şekilde kanser ve sağıklı hücrelerde mitokondriyal membran potansiyelinde $\left(D \Psi_{m}\right)$ önemli ölçüde bir azalma meydana getirmiştir. Artan hücre içi ROS ve MMP düzeyleri arasında güçlü bir negatif korelasyon olduğunu gösterdik. Daha önce yapılan çalışmalar DADS ve DATS'ın kanser hücre- 
lerinde MMP'yi düşürüp apoptoza neden olduğundan verilerimiz önceki çalışmalar ile uyumludur (36-38).

GSH bir antioksidan moleküldür ve hücreleri ROS'a karşı koruduğundan hücresel hemostaz için önemli bir göstergedir (39). Çalışmamızda kanser ve sağlıkı hücre hatlarında DADS ve DATS'ın 24 saatlik inkübasyonu sonrası doza bağlı olarak GSH düzeylerinde azalma meydana gelmiştir. Artan hücre içi ROS düzeyleri ile azalan GSH düzeyleri arasında güçlü bir korelasyon bulduk. Azalan GSH düzeyleri özellikle kanser hücrelerini hücre içi ROS'un etkisine karşı daha duyarlı hale getirmiş̧tir.

Çalışmamızda DADS ve DATS'ın genotoksik aktivitesini alkali tek hücre elektroforezi ile değerlendirmek için $\mathrm{IC}_{50}$ altındaki dozlarını kanser ve sağıklı hücrelerde 24 saat inkübe ettik. Genotoksisiteyi yani DNA Hasarını değerlendirmek için comet assay metodu en önemli yöntemlerden biridir. DATS ve DATS'ın doza bağı bir şekilde DNA hasarını indüklediğini gösterdik ve kanser hücrelerinin sağlıklı hücrelere göre hasara daha duyarlı olduğunu gözlemledik. Son yapılan çalışmalarda genotoksik aktivite farklı hücrelerde comet assay metodu ile değerlendirilmiş (40) ve bizim sonuçlarımızla uyumlu bulunmuştur. Kanser hücrelerinde artan hücre içi ROS'un DNA hasarını ve apoptozu tetiklediğini gösteren çalışmalar mevcuttur (40). Bu çalışmamız ile DADS ve DATS'ın neden olduğu artan hücre içi ROS düzeyleri DNA hasarını ve apoptozu indüklediğini gösterdik.

Apoptoz indüksiyonu DADS ve DATS kaynaklı ölüm mekanizmalarından biridir (10). Hücrelerde meydana gelen apoptozu AT/EB çift boyama yöntemiyle floresans mikroskopta tayin ettik. Bu yöntemde apoptotik, nekrotik ve canlı hücreleri görüntüleyerek hücreleri yarıkantitatif olarak sayıp hesapladık. Hücreleri AT/EB ile boyadıktan sonra canlı, sağ Iklı hücreler yeşil, apoptotik hücreler turuncu ve kromatin yoğunlaşmasından dolayı fragmante çekirdekli ve nekrotik hücreler kırmızı renkte gözlendi. Çalışmamızda DADS ve DATS ile 24 saat inkübe edilen prostat kanser ve sağ Iıklı hücrelerinde doza bağlı bir şekilde apoptozda artış gözlenmiştir. Kanser hücrelerindeki relatif apoptoz düzeyi sağlıklı hücrelere göre daha yüksek olduğu ortaya konulmuştur. Çalışmamızdaki sonuçlar literatürdeki DADS ve DATS'ın diğer hücreler üzerindeki apoptoza etkileri ile uyumludur $(10,36)$. Prostat sağlıklı ve kanser hücrelerinde artan hücre içi ROS düzeylerinin artan apoptoz ile güçlü pozitif bir korelasyona sahip olduğunu bulduk. Bu durum hücrelerin apoptoz üzerinden sitotoksisiteye gitmesine neden olabilir.

Prostat kanser ve sağlıklı epitel hücrelerinde artan konsantrasyonda DADS ve DATS'ın hücre içi ROS'u ve $\mathrm{Ca}^{2+} \mathrm{\prime} u$ arttırıp, hücre içi GSH ve MMP'yi düşürerek sitotoksisite, genotoksisite ve apoptozu indüklendiği gösterilmiştir. Sonuç olarak antioksidan özellik gösteren DADS ve DATS'ın yüksek konsantrasyonlarının kanser hücrelerinde prooksidan etki gösterdiği ve ölüm mekanizmalarını tetiklediği gösterilmektedir (Şekil 10).

Özetle mevcut sonuçlarımızda DADS ve DATS'ın kanser hücrelerinde sitotoksisite, genotoksisite ve apoptozu sağlıklı hücrelere göre doz bağımlı olarak daha fazla indükleyebildiği gösterilmiştir. Literatürde DADS ve DATS gibi sülfürlü bileşiklerin kanser hücreleri üzerinde sitotoksik, genotoksik ve apoptotik etkileri ayrı ayrı ele alınmıştır. Çalışmamızın özgünlüğü, DADS ve DATS'ın bu etkileri hem prostat kanser hücresinde hem de sağlıklı prostat epitel hücresinde göstermenin yanında apoptotik yolu indükleyen MMP azalması ve $\mathrm{Ca}^{2+}$ artışı ile sitotoksisite ve DNA hasarını indükleyen hücre içi ROS'un artışı ve glutatyon azalışını bir arada göstermesi nedeniyle literatüre ışık tutmuştur. Tüm bu verilerimiz birlikte ele alındığında DADS ve DATS'ın bu etkileri prostat kanser tedavisi için etkili bir strateji olabilir.

\section{Açıklamalar}

Teşekkür: Bu çalışma 14 Mart 2017'de Bezmialem Vakıf Üniversitesi "Annual Medical Students Research Presentation Day" de kısa sözlü bildiri olarak sunulmuştur.

Çıkar Çatışması: Yazarlar aralarında çıkar çatışması olmadığını beyan eder.

Finansal Destek: Bezmialem Vakıf Üniversitesi Bilimsel Araştırma Projeleri Biriminin 6.2016/35 nolu projesi ile desteklenmiştir.

Etik Onam: Çalışmamız in vitro hücre kültürü çalışması olduğu için herhangi bir etik onama intiyaç duyulmamaktadır.

\section{Kaynaklar}

1. Pienta KJ, Smith DC. Advances in Prostate Cancer Chemotherapy: A New Era Begins 1. CA Cancer J Clin. 2005;55(5):300-18.

2. Leyh-Bannurah S-R, Gazdovich $S$, Budäus L, Zaffuto E, Briganti $A$, Abdollah $\mathrm{F}$, et al. Local therapy improves survival in metastatic prostate cancer. Eur Urol. 2017;72(1):118-24.

3. Mukherjee AK, Basu S, Sarkar N, Ghosh AC. Advances in cancer therapy with plant based natural products. Curr Med Chem. 2001;8(12):1467-86.

4. Ross SA, Milner JA. Garlic: the mystical food in health promotion. Handbook of nutraceuticals and functional foods: CRC Press; 2016. p. 84-110.

5. Iciek M, Kwiecień I, Włodek L. Biological properties of garlic and garlic-derived organosulfur compounds. Environ Mol Mutagen. 2009;50(3):247-65.

6. Cao G, Sofic E, Prior RL. Antioxidant capacity of tea and common vegetables. J Agric Food Chem. 1996;44(11):3426-31.

7. Nagini S. Cancer chemoprevention by garlic and its organosulfur compounds-panacea or promise? Anticancer Agents Med Chem. 2008;8(3):313-21.

8. Kaschula $\mathrm{CH}$, Hunter R, Parker MI. Garlic-derived anticancer agents: Structure and biological activity of ajoene. Biofactors. 2010;36(1):78-85. 9. Harris J, Cottrell S, Plummer S, Lloyd D. Antimicrobial properties of Allium sativum (garlic). Appl Microbiol Biotechnol. 2001;57(3):282-6.

10. Hosono T, Fukao T, Ogihara J, Ito Y, Shiba H, Seki T, et al. Diallyl trisulfide suppresses the proliferation and induces apoptosis of human colon cancer cells through oxidative modification of $\beta$-tubulin. J Biol Chem. 2005;280(50):41487-93.

11. Tan $\mathrm{H}$, Ling H, He J, Yi L, Zhou J, Lin M, et al. Inhibition of ERK and activation of p38 are involved in diallyl disulfide induced apoptosis of leukemia HL-60 cells. Arch Pharm Res. 2008;31(6):786. 
12. Kocyigit A, Guler EM, Karatas E, Caglar H, Bulut H. Dose-dependent proliferative and cytotoxic effects of melatonin on human epidermoid carcinoma and normal skin fibroblast cells. Mutat Res Genet Toxicol Environ Mutagen. 2018;829:50-60.

13. Kocyigit A, Guler EM, Karatas E, Caglar H, Bulut H. Dose-dependent proliferative and cytotoxic effects of melatonin on human epidermoid carcinoma and normal skin fibroblast cells. Mutat Res. 2018;829830:50-60.

14. Untario N, Dewi TC, Widodo MA, Rahaju P. Effect of Tetrodotoxin from Crude Puffer Fish (Tetraodon fluviatilis) Liver Extract on Intracellular Calcium Level and Apoptosis of HeLa Cell Culture. J Trop Life Sci. 2017;7(1):23-9.

15. Rottenberg H, Wu S. Quantitative assay by flow cytometry of the mitochondrial membrane potential in intact cells. Biochim Biophys Acta Mol Cell Res. 1998;1404(3):393-404.

16. Günes-Bayir A, Kiziltan HS, Kocyigit A, Güler EM, Karataş E, Toprak A. Effects of natural phenolic compound carvacrol on the human gastric adenocarcinoma (AGS) cells in vitro. Anti-cancer drugs. 2017;28(5):522-30.

17. Singh NP, Danner DB, Tice RR, Brant L, Schneider EL. DNA damage and rpair with age in individual human lymphocytes. Mutat Res. 1990;237(3-4):123-30.

18. Demirbag R, Yilmaz R, Gur M, Kocyigit A, Celik H, Guzel S, et al. Lymphocyte DNA damage in patients with acute coronary syndrome and its relationship with severity of acute coronary syndrome. Mutat Res Fund Mol Mech Mutagen. 2005;578(1-2):298-307.

19. Kasibhatla S, Amarante-Mendes GP, Finucane D, Brunner $T$, Bossy-Wetzel E, Green DR. Acridine Orange/Ethidium Bromide (AO/EB) Staining to Detect Apoptosis. CSH Protoc. 2006;2006(3).

20. Komura K, Sweeney CJ, Inamoto T, Ibuki N, Azuma H, Kantoff PW. Current treatment strategies for advanced prostate cancer. International Journal of Urology. 2018;25(3):220-31.

21. Song Y-h, Sun H, Zhang A-h, Yan G-I, Han Y, Wang X-j. Plant-derived natural products as leads to anti-cancer drugs. J Med Plant Herb Ther Res. 2014;2:6-15.

22. Schumacker PT. Reactive oxygen species in cancer cells: live by the sword, die by the sword. Cancer cell. 2006;10(3):175-6.

23. Ling $H$, Zhang L-Y, Su Q, Song Y, Luo Z-Y, Zhou XT, et al. Erk is involved in the differentiation induced by diallyl disulfide in the human gastric cancer cell line MGC803. Cell Mol Biol Lett. 2006;11(3):408.

24. Knowles L, Milner J. Diallyl disulfide induces ERK phosphorylation and alters gene expression profiles in human colon tumor cells. J Nutr. 2003;133(9):2901-6.

25. Lai KC, Hsu SC, Kuo CL, Yang JS, Ma CY, Lu HF, et al. Diallyl sulfide, diallyl disulfide, and diallyl trisulfide inhibit migration and invasion in human colon cancer colo 205 cells through the inhibition of matrix metalloproteinase-2,-7, and-9 expressions. Environ Toxicol. 2013;28(9):479-88.

26. Druesne-Pecollo N, Pagniez A, Thomas M, Cherbuy C, Duée P-H, Martel $\mathrm{P}$, et al. Diallyl disulfide increases CDKN1A promoter-associated histone acetylation in human colon tumor cell lines. J Agric Food Chem. 2006;54(20):7503-7.

27. Xiao D, Pinto JT, Gundersen GG, Weinstein IB. Effects of a series of organosulfur compounds on mitotic arrest and induction of apoptosis in colon cancer cells. Mol Cancer Ther. 2005;4(9):1388-98.

28. Yin M-c, Hwang S-w, Chan K-c. Nonenzymatic antioxidant activity of four organosulfur compounds derived from garlic. J Agric Food Chem. 2002;50(21):6143-7.

29. Wu X-J, Kassie F, Mersch-Sundermann V. The role of reactive oxygen species (ROS) production on diallyl disulfide (DADS) induced apoptosis and cell cycle arrest in human A549 lung carcinoma cells. Mutat Res Fund Mol Mech Mutagen. 2005;579(1-2):115-24.

30. Yordi EG, Pérez EM, Matos MJ, Villares EU. Antioxidant and prooxidant effects of polyphenolic compounds and structure-activity relationship evidence. Nutrition, well-being and health. 2012;10:29471.
31. Das A, Banik NL, Ray SK. Garlic compounds generate reactive oxygen species leading to activation of stress kinases and cysteine proteases for apoptosis in human glioblastoma T98G and U87MG cells. Cancer. 2007;110(5):1083-95.

32. Liao Y, Bai H, Li Z, Zou J, Chen J, Zheng F, et al. Longikaurin A, a natural ent-kaurane, induces $\mathrm{G} 2 / \mathrm{M}$ phase arrest via downregulation of Skp2 and apoptosis induction through ROS/JNK/c-Jun pathway in hepatocellular carcinoma cells. Cell Death Dis. 2014;5(3):e1137-e.

33. Berridge MJ. Calcium microdomains: organization and function. Cell Calcium. 2006;40(5-6):405-12.

34. Hajnóczky G, Csordás G. Calcium signalling: fishing out molecules of mitochondrial calcium transport. Curr Biol. 2010;20(20):R888-91.

35. Ly JD, Grubb DR, Lawen A. The mitochondrial membrane potential $(\Delta \psi \mathrm{m})$ in apoptosis; an update. Apoptosis. 2003;8(2):115-28.

36. Kim Y-A, Xiao D, Xiao H, Powolny AA, Lew KL, Reilly ML, et al. Mitochondria-mediated apoptosis by diallyl trisulfide in human prostate cancer cells is associated with generation of reactive oxygen species and regulated by Bax/Bak. Mol Cancer Ther. 2007;6(5):1599-609.

37. Truong D, Hindmarsh W, O'Brien P. The molecular mechanisms of diallyl disulfide and diallyl sulfide induced hepatocyte cytotoxicity. Chem Biol Interact. 2009;180(1):79-88.

38. Choi YH, Park HS. Apoptosis induction of U937 human leukemia cells by diallyl trisulfide induces through generation of reactive oxygen species. J Biomed Sci. 2012;19(1):50.

39. Lushchak VI. Glutathione homeostasis and functions: potential targets for medical interventions. J Amino Acids. 2012;2012.

40. Sielicka-Dudzin A, Borkowska A, Herman-Antosiewicz A, Wozniak M, Jozwik A, Fedeli D, et al. Impact of JNK1, JNK2, and ligase Itch on reactive oxygen species formation and survival of prostate cancer cells treated with diallyl trisulfide. Eur J Nutr. 2012;51(5):573-81. 